\title{
Left behind? Gender gaps in political engagement over the life course in 27 European countries ${ }^{1}$
}

\section{Mario Quaranta}

Department of Political and Social Sciences

European University Institute

Via dei Roccettini, 9

50014 San Domenico di Fiesole - Italy

mario.quaranta@eui.eu

\section{Giulia M. Dotti Sani}

Department of Political and Social Sciences

European University Institute

Via dei Roccettini, 9

50014 San Domenico di Fiesole - Italy

giulia.dottisani@eui.eu

Mario Quaranta is a Max Weber Fellow in the Department of Political and Social Sciences at the European University Institute, Florence. His research interests lie in the fields of comparative political participation and public opinion. He has recently published articles in the European Political Science Review, Information, Communication \& Society, and Sex Roles.

Giulia M Dotti Sani is a Max Weber Fellow in the Department of Political and Social Sciences at the European University Institute. Her main research areas are sociology of the family, social stratification, gender and household inequalities in an international perspective. Her works appear in international peer-reviewed journals such as the European Sociological Review, European Journal of Political Research, and Sex Roles.

Acknowledgements. A previous version of this article was presented at the 5th European Conference on Politics and Gender at the University of Lausanne. We would like to thank the panel participants for the helpful feedback. We also thank the anonymous reviewers and the Editor for their thorough reading and valuable comments. Authors contributed equally to this work.

\footnotetext{
${ }^{1}$ Article published as: Mario Quaranta and Giulia M. Dotti Sani (2018). Left behind? Gender gaps in political engagement over the life course in 27 European countries. Social Politics. 25, 2, 254-286. DOI: doi.org/10.1093/sp/jxy005.
} 


\begin{abstract}
This article investigates gender differences in political involvement in 27 countries across four life course stages: home-leaving, partnership formation, parenthood and empty nest. Single country studies show that these life events can hamper women's political engagement, but whether this finding holds cross-nationally remains unclear. Using European Social Survey data, we show that across countries "family intensive" life course stages have a stronger negative effect on women's involvement than men's, but more on political interest, party identification and activity, than voting or demonstrating. Further, women's macro-level political representation only partially accounts for cross-national differences in life cycle effects on political involvement.
\end{abstract}

Keywords: political participation; life course; life transitions; gender gap; Europe 


\section{Introduction}

This article investigates cross-national differences in political engagement among European women and men at different stages of the life course. Previous studies have concentrated on betweencountry differences in political involvement on the one hand (Abendschön and Steinmetz 2014; Beauregard 2014; Coffè and Bolzendahl 2013; Desposato and Norrander 2009; Fraile 2014), and on within-country differences in political engagement over the life course on the other (Burns, Schlozman, and Verba 1997; Highton and Wolfinger 2001; Jennings 1979; Stoker and Jennings 1995; Voorpostel and Coffé 2010). The literature currently lacks a large-scale comparative study on the relationship between life course events and women's and men's engagement in politics that could grant us a better understanding of how gender inequalities in politics unfold over the life cycle in different institutional settings. This article fills this gap by investigating the link between political involvement and four key life course stages among women and men in 27 European countries: leaving the parental home, partnership formation, parenthood and the empty nest.

Political inequality is an important part of societal gender inequality. Women's limited representation in national parliaments and governments and their low levels of political interest and bottom-up participation are strongly detrimental to the overall cause of gender equality (Bleijenbergh and Roggeband 2007; EIGE 2015; IPU 2014; Morgan and Zippel 2003). Politically active and engaged citizens can voice their needs and consequently improve their conditions (e.g. Lijphart 1997). In this respect, a greater commitment of women in the political field would have positive spillovers in relevant areas such as female labor force participation, the division of domestic labor and childcare responsibilities (Allik 2016; Bleijenbergh and Roggeband 2007; Kittilson 2008; Walby 2004). Therefore, gaining a deeper understanding of gender inequalities in political engagement is important from a scholarly as well as a societal point of view.

Much previous research has shown that gender gaps in political engagement and interest can partially be explained by early socialization to gendered roles, different constraints in paid and unpaid labor, and unequal access to economic and human capital (Abendschön and Steinmetz 2014; Burns, Schlozman, and Verba 1997, 2001; Finseraas, Jakobsson, and Kotsadam 2012; Fraile 2014; Inglehart and Norris 2003; Lovenduski 1998; Schlozman, Burns, and Verba 1999; Welch 1977). 
The literature has also revealed the importance of life course events in shaping women's and men's political actions (Quaranta 2016; Stoker and Jennings 1995; Verba, Burns, and Schlozman 1997; Wolfinger and Wolfinger 2008). Becoming a parent, for example, is a life changing event that can strongly affect political engagement by changing new parents' priorities and curtailing time for individual interests, including politics. Consequently, political involvement may be less frequent during "family dense" stages of life, especially among women. However, most of the literature on the relationship between life course events and women's and men's engagement in politics is based on single country studies, such as the US (Wolfinger and Wolfinger 2008), Switzerland (Voorpostel and Coffé 2010) or Italy (Quaranta 2016). The first contribution of the article, therefore, is to test whether these findings can be generalized to a wider pool of European countries.

Whether women and men engage in politics to different extents is not just a matter of individual characteristics and life trajectories: contextual features are important drivers of political participation. For example, gender gaps in political engagement and interest are smaller in countries with power sharing institutions (Kittilson and Schwindt-Bayer 2010) and greater societal gender equality (Fraile and Gomez 2017). Contrary to this, women are less likely to hold political and economic power and be politically active in countries with greater inequality in the domestic sphere (EIGE 2015; Vassallo 2006). Here, we consider whether contextual political equality, in the form of women's representation in political decision-making positions, might mediate the relationship between engagement and life course events. Women's representation, in fact, seems to be associated with narrower gender gaps in politics (see Desposato and Norrander 2009; Reingold and Harrell 2010; Wolbrecht and Campbell 2007) as it indicates a more favorable environment for their engagement in the public sphere. Hence, the second contribution of the article is to test whether a crucial macro-level variable - women's representation in political decision-making positions - is associated with political engagement among women and men at different stages of the life course. If political gender equality effectively enhances women's political engagement throughout the life cycle, a case can be made in support of policies that foster the greater presence of women in the political field.

Finally, most prior research has addressed one or at best few forms of political engagement at once (Abendschön and Steinmetz 2014; Fraile and Gomez 2017; Goerres 2007; Highton and Wolfinger 
2001). However, political activities require varying degrees of time and commitment: some are less demanding and thus more "family-friendly" than others (see Coffee and Bolzendahl 2013; Quaranta 2016; Voorpostel and Coffé 2010). Voting, for example, is a low-impact type of involvement in which women and men participate to similar extents (Smets and Van Ham 2013). It is therefore an open question whether gender gaps in political involvement over the life course differ by type of activity. Hence, this article adopts a comprehensive approach by analyzing five key forms of political involvement: political interest, feeling close to a party, voting, party activity and taking part in demonstrations. These represent an optimal tool with which to investigate gender gaps in political involvement over the life course because they are qualitatively dissimilar and require very different levels of time and commitment (see Ekman and Amna 2012; Teorell, Torcal, and Montero 2007).

We address these issues using multilevel models on seven rounds of European Social Survey data for 27 countries. Our results show that, across Europe, there is a gender gap in some, but not all, forms of political involvement. The findings also show that "family dense" stages of life have a stronger negative effect on women's involvement than on men's. In addition, the analyses indicate that there is little cross-national variation in the gender gap in political engagement, and that such variation is not fully accounted for by differences in women's representation in decision-making positions.

Citizens who voice their needs through political activity are more likely to improve their conditions, but citizens who are better off to begin with might also be more likely to be politically engaged. Our findings are therefore unsettling, as they suggest that gender inequalities in the private sphere translate into political inequalities that ultimately reduce women's chances of improving their status, in a vicious cycle that is proving troublesome to break.

\section{Theoretical background}

\section{Gender and political engagement}

It is widely recognized that women are generally less involved in politics than men (Inglehart and Norris 2003). Three broad and interrelated explanations account for this gap by calling upon socialization processes, and situational and structural factors (Burns, Schlozman, and Verba 1997; Lovenduski 1998; Welch 1977). 
The first argues that women and men are differently socialized with respect to their role in the public and political sphere (Verba, Burns, and Schlozman 1997). Men are pushed into politics by gender norms and expectations, while women are "socialized into a politically passive role" (Welch 1977, 13). Girls are generally encouraged to emphasize the importance of social relationships, while boys the relevance of status and independence (Gilligan 1982). Indirectly, this process shapes orientations towards politics (Fridkin and Kenney 2007): various studies find gender gaps in the quantity and quality of political engagement as early as childhood and adolescence (Eckstein, Noack, and Gniewosz 2012; Ferrin, Fraile, and Rubal 2015).

A second, related explanation for the gender gap in politics considers situational factors, such as family and household responsibilities. As women are more involved in caring activities, they have fewer opportunities and less time to engage in politics than men. Thus, women's roles hinder their engagement (Jennings and Farah 1980; Stoker and Jennings 1995) and household inequalities turn into political inequalities (Burns, Schlozman, and Verba 1997).

The last set of explanations emphasizes the role of socioeconomic and structural factors, arguing that women lack the resources that are associated with political involvement, such as education, income, civic skill and networks (see Schlozman, Burns, and Verba 1999). For reasons linked to socialization and constraints, women tend to have qualitatively different education ${ }^{\mathrm{i}}$ and, when employed, lower status in employment and wages than men (OECD 2016). In contrast, men are more likely to hold central roles in society that expose them to political stimuli and give them resources to be politically active (Schlozman, Burns, and Verba 1999). In line with this reasoning and with previous research, we anticipate that women will be less politically engaged than men. However, we expect the gender gap to vary by stage of the life course.

\section{Life course stages and political engagement among men and women}

Beyond the three interwoven explanations discussed above, the literature on political involvement has explored the role of the life cycle for political outcomes, mostly relying on age as a proxy for different opportunities, constraints, and resources. Previous research has found that working age individuals are more likely to be politically engaged than younger and older ones (Zukin et al. 2006). 
By developing abilities and gaining resources with which to participate over time, individuals become progressively more involved in the polity but tend to retire from public life when they become older. If political engagement changes during the life cycle, however, it is also because individuals' roles evolve and, with them, so do situational constraints and opportunities. Importantly, the different roles that women and men undertake during the life course might result in heterogeneity in the association between various life stages - and the related resources - and political involvement. If resources that are important for engagement, such as time or income, differ substantially across the life course among men and women (Schlozman, Burns, and Verba 1994), it is reasonable to expect gender-specific associations between life stages and political engagement.

The attention to specific stages of the life course has not been systematic in the literature on political and civic engagement, but previous studies have identified four pivotal life course stages: 1) independent living; 2) partnership formation; 3) parenthood; 4) empty nest (Elder and Greene 2012; Highton and Wolfinger 2001; Lancee and Radl 2014; Quaranta 2016; Stoker and Jennings 1995; Voorpostel and Coffé 2010; Wolfinger and Wolfinger 2008). Each of these represents a distinct phase of life with different responsibilities, psychological capacities, cultural and human capital, social skills and networks, values, interests and preferences, and has different implications for men and women (Buchmann and Kriesi 2011; Marini 1984).

Chronologically, the first life course transition is leaving the parental home (Buchmann and Kriesi 2011). During this stage, subjects take on new responsibilities related to employment and independent living, and experience changes in social networks and in their levels of personal, political and financial autonomy. These changes might increase young individuals' interest toward political issues (Highton and Wolfinger 2001; Plutzer 2002) and represent opportunities for participation to both women and men (Flanagan and Levine 2010). However, resources that are important for engagement, such as time and income, decrease when leaving the parental home (Gauthier and Furstenberg 2002) thus potentially reducing the opportunities for political involvement. The few studies that address this point present contrasting results. Studies on the US (Highton and Wolfinger 2001) and on Denmark (Bhatti and Hansen 2012) indicate that leaving the parental home negatively affects the likelihood of turnout. Hooghe (2003) for Belgium shows that engagement in associations is not affected by leaving 
the parental home, while Van Ingen (2008) for the Netherlands finds that this transition strengthens informal types of engagement. None of the mentioned articles explicitly model gender differences in their analyses, but they suggest that home leaving is unlikely to yield gender differences in political outcomes because during this phase women and men alike are more focused on finding a partner or a stable job than on political engagement (Converse 1971). To test this reasoning, we formulate the following hypothesis:

Hypothesis 1: Leaving the parental home is not associated with gaps in involvement between women and men.

The second stage we consider is partnership formation. On the one hand, studies have shown that partnership favors attention to politics, interest and political efficacy, turnout and community involvement (Verba, Burns, and Schlozman 1997; Wolfinger and Wolfinger 2008). On the other hand, being in a union implies an increase in private responsibilities and therefore a reduction in time for politics (Burns, Schlozman, and Verba 1997). The empirical results in this respect are contrasting: some studies find a negative association between union formation and political engagement (Hooghe 2003; Stoker and Jennings 1995), while others find no effect at all (Highton and Wolfinger 2001; Jennings and Niemi 1981; Oesterle, Kirkpatrick Johnson, and Mortimer 2004; Voorpostel and Coffé 2010). Union formation, however, has very different consequences on the lives of women and men: during this life stage women increase the time spent on unpaid labor but decrease the time spent on paid employment, although the magnitude of this effect varies across countries (Baxter, Hewitt, and Haynes 2008; Gauthier and Furstenberg 2002; Anxo et al. 2011). In this regard, gender can be an obstacle to political engagement (Burns, Schlozman, and Verba 1997; Schlozman, Burns, and Verba 1999) because time spent in the workplace can prompt political interest, discussion, and participation, whereas time spent on domestic work cannot. Empirical studies on this point rely on single-country cases and present contrasting results. Early research on the US finds that marital status does not affect the participation of either women or men (Welch 1977), while more recent evidence suggests that divorce has a positive effect on volunteering but only for men (Nesbit 2012). For Europe, a Swiss study finds a negligible effect of partnership formation on both women and men (Voorpostel and Coffé 2010), whereas an Italian 
study shows that union formation has a negative effect on women's engagement and a positive one on men's (Quaranta 2016). Based on these findings, we formulate and test the following hypothesis:

Hypothesis 2: Being in a partnership is associated with gaps in political involvement between women and men.

The third stage we focus on is parenthood. Childrearing is important to politics, as it increases parents' awareness about public issues, changes political preferences and personal resources, and represents an opportunity for political engagement (Elder and Greene 2012; Flanagan et al. 2012). Compared to childless individuals, parents extend their social networks, become aware of community issues and get involved in local activities that concern their children's welfare. Studies based on the US, for example, find a positive association between parenthood and political/community involvement (Jennings 1979; Oesterle, Kirkpatrick Johnson, and Mortimer 2004) and an interest in politics (Elder and Greene 2012). However, children also represent a constraint to engagement, especially when they are very young: they affect the time available for politics, represent a strain on social relationships and networks, and push individuals to focus on the private, rather than the public sphere (Gauthier and Furstenberg 2002; Nomaguchi and Milkie 2003). Research on the US finds that having children is associated with weaker attention paid to political campaigns and turnout (Wolfinger and Wolfinger 2008; Welch 1977). Other studies, however, argue that the effect of parenthood on political involvement depends on the age of the children. The demands of having very young children - in terms of time and resources - isolate parents from politics, whereas among parents of school-age children political involvement is higher (Nesbit 2012; Schlozman, Burns, and Verba 1994). Finally, some studies find no significant association between the presence of children and political engagement whatsoever (Burns, Schlozman, and Verba 2001). Parenthood, however, has different consequences for men and women, especially when children are very young (Anxo et al. 2011; Gauthier and Furstenberg 2002). Mothers often interrupt or quit their job - with a loss in wages and career opportunities - and increase the time devoted to childcare and housework (Boeckmann, Misra, and Budig 2015; Dotti Sani and Scherer 2017; Schober 2013). The opposite holds true for fathers (Killewald 2013). In line with these findings, studies from various national contexts show that the effect of parenthood on political involvement is more pronounced among mothers, at least until the children reach school age (Schlozman, Burns, and Verba 
1994, 1999; Quaranta 2016; Voorpostel and Coffé 2010). Moreover, in the US, mothers and childless women differ in terms of political information, efficacy, knowledge and trust (Jennings and Niemi 1981). The literature is far from conclusive, but suggests that women are more prone to modify their daily lives in relation to parenthood than men. Thus, we test the following hypothesis:

Hypothesis 3: Parenthood is associated with gaps in involvement between women and men, especially when children are young and less so when children grow older.

The fourth and final stage we consider is the "empty nest" phase. Most research shows that individuals retreat and disengage from the political sphere as they age, but that demanding modes of involvement, such as demonstrating, are more likely to decline than passive ones, such as an interest in politics (Goerres 2007, 2009; Jennings and Markus 1988; Nie, Verba and Kim 1974). Moreover, beyond a certain age, gender differences in time and resources tend to diminish: employed women and men retire and thus the gap with homemakers becomes narrower (Anxo et al. 2011). Few studies address gender inequalities in political involvement in the older age group. The early study by Nie, Verba and Kim (1974) finds older men are more likely to engage in politics than women but also shows a declining trend in participation among women and men alike in five different countries. A more recent study on Germany, instead, reveals that the decline in political participation occurs faster among women than among men, but gender differences eventually disappear among the oldest individuals (Bukov, Maas, and Lampert 2002). Goerres (2009), in his comparative European study, shows that even among the older subjects there is a gender gap in unconventional political participation. In line with these results, we formulate our fourth hypothesis:

Hypothesis 4: The empty nest phase is associated with gaps in involvement between women and men.

\section{Gender, life course and societal differences}

To fully comprehend gender inequalities in politics over the life course it is essential to study women's and men's behaviors in relation to the institutional settings in which they are embedded. Indeed, research suggests that women's chances of being politically involved are not distributed evenly 
across national contexts, but rather that certain settings are more favorable for women's political engagement.

From a political point of view, research has shown that institutions play an important role in promoting political equality between women and men (Kittilson and Schwindt-Bayer 2010). In particular, power-sharing political systems favor the involvement of underrepresented groups and therefore women (Beauregard 2014; Kittilson and Schwindt-Bayer 2010). Another explanation for cross-national gender gaps in political engagement is the presence of women in political institutions, with women being more involved in contexts where they have greater descriptive representation (Burns, Schlozman, and Verba 2001; Desposato and Norrander 2009; Reingold and Harrell 2010; Wolbrecht and Campbell 2007). For example, Wolbrecht and Campbell (2007) find that descriptive representation narrows gender differences in political participation among adolescents. The findings suggest a socialization effect by which female politicians serve as role models, inspiring young women to become politically active. Another stream of research goes beyond political aspects and considers socioeconomic differences between women and men at the country level to account for cross-national differences in political engagement. These studies suggest that countries with widespread gender egalitarianism offer greater opportunities for women to engage and be interested in politics (Coffé and Dilli 2015; Fraile and Gomez 2017).

Our final hypothesis addresses cross-national variations of life cycle effects on political engagement. Currently, there is no empirical evidence showing that life course effects can be moderated by contextual features. To fill this gap, we explore whether a greater presence of women in politics, measured through their representation in decision-making positions at the local, regional and national level (EIGE, 2015), is associated with smaller gender gaps in political involvement over the life course. Two compelling arguments back up this expectation. First, if the political arena is not dominated by men (EIGE 2015; IPU 2014), women might identify with female politicians and thus feel more entitled to be politically active, regardless of life course stage. Second, previous studies have shown that female politicians are more likely to represent women's interests and thus to pursue women- and family-friendly policies (Allik 2016; Bleijenbergh and Roggeband 2007; Walby 2004) that might remove some of the barriers towards women's political engagement, even during family-intense stages of life. For example, 
Allik (2016) argues that the high levels of social and in-kind family spending in social democratic countries - that typically benefit women - can be traced back to the large presence of female representatives in parliament. The combination of a sense of belonging in politics and identification with female leaders, plus the removal of barriers to political activity, should effectively minimize gender gaps in political engagement. Therefore, we hypothesize the following:

Hypothesis 5: At all stages of the life course, the gaps in political involvement between women and men will be smaller in countries with higher levels of women's representation in decision-making positions.

\section{Research design}

Data

To test the association between life course stages and political involvement we use data from seven waves of the European Social Survey (ESS, 2002-2014). The ESS is a biannual survey held in over 30 European countries plus Israel and it includes several items measuring political involvement. Importantly, it provides crucial information on the respondents' household - such as partnership status and the age of co-resident children - that allow us to gauge the effects of the life cycle on political engagement ${ }^{\mathrm{ii}}$. Finally, thanks to its repeated wave design, it is among the few comparative datasets with large enough country samples to guarantee reliable estimates.

As a result of the lack of comparable macro-level data, non-EU democratic countries (Norway, Switzerland and Iceland), non-democratic and/or non-EU countries (e.g. Turkey and Israel) were excluded from the analyses, thus leaving us with a restricted sample of 27 European democratic countries: Austria, Belgium, Bulgaria, Croatia, Cyprus, Czech Republic, Denmark, Estonia, Finland, France, Germany, Greece, Hungary, Ireland, Italy, Latvia, Lithuania, Luxembourg, Netherlands, Poland, Portugal, Romania, Slovakia, Slovenia, Spain, Sweden, and United Kingdom.

\section{Dependent variables}

The analyses engage in a comprehensive study of the relationship between the life course and political engagement in Europe by considering five qualitatively different types of engagement: showing 
political interest that is a private and latent act and is often considered a pre-condition for other forms of involvement; showing attachment to political groups, as for instance political parties; engaging in formal acts of participation, such as voting or party activity; and getting involved in extra-representative or unconventional acts of participation, such as demonstrations (Ekman and Amna 2012; Teorell, Torcal, and Montero 2007). In practice, we utilize five dichotomous items capturing whether the respondent: 1) is interested in politics, ${ }^{. i i}$ 2) is close to a party (as a measure of party identification); 3 ) has voted at the last national elections; 4) has worked for a political party or a political action group in the last 12 months; 5) has attended a demonstration in the last 12 months.

\section{Independent variables}

Following previous studies (Anxo et al. 2011; Gauthier and Furstenberg 2002; Highton and Wolfinger 2001; Nisbet 2012; Quaranta 2016), the independent variable of interest classifies respondents according to four biographical stages: living with parents vs. having left the parental home; living with a partner in a stable relationship (either married or cohabiting); being a parent; being in the empty nest phase. We add analytical depth to the classification by also taking into account the age of the respondents and, among parents, the age of the children. By crossing biographical stages with age and age of the children we obtain seven life course stages: 1) being single, childless, aged 18-35 and living with parents; 2) being single, childless, aged 18-35 and living independently; 3) being in a partnership (cohabitation or marriage), aged 18-45 and childless; 4) being in a partnership and having a child aged 0-5 (pre-school age); 5) being in a partnership and having a child aged 6-13; 6) being in a partnership and having a child aged 14-25; 7) being aged 65 and above without children in the household. Like previous studies (e.g. Anxo et al. 2011; Quaranta 2016), we focus on core and standard life course stages and exclude individuals who do not fall into the categories described above (e.g. single parents). Indeed, this classification represents a parsimonious variable gauging different statuses - or household structures - of a "typical" life cycle (Marini 1984). It does not account for life course sequences that do not follow such typical paths (Buchmann and Kriesi 2011) and cannot be interpreted as a dynamic tool to capture life transitions. 
Several individual characteristics are then included as controls. First, we include three variables to capture socioeconomic status that proxy fundamental individual resources for political involvement: education (in years), employment status $(0=$ not employed; $1=$ employed $)$ and feelings about household income $(0=$ finding it difficult or very difficult to cope on present income; $1=$ coping or living comfortably on present income). Then we include trust in people (from $0=$ no trust, to $10=$ complete trust) as this is considered a proxy of larger social networks and interactions favoring political involvement (Stoker and Jennings 1995). Life satisfaction (from $0=$ no satisfaction, to $10=$ complete satisfaction) is also included because it may foster conventional forms of engagement while dissatisfaction may trigger unconventional ones (Flavin and Keane 2012). Eventually, we control for satisfaction with democracy (from $0=$ no satisfaction, to $10=$ complete satisfaction), as it has been shown to be associated with a number of forms of political engagement, given its links to democratic norms and values (Dalton 2004). Ideology is also an important component of ones' political world. In particular, left-right positioning reflects a set of political values that are variously associated with involvement in politics (Inglehart 1997). Thus, individual position on the left-right scale is included as a categorical variable (no answer/don't know as reference category; extreme left; left; center; right; extreme right) to capture possible non-linear effects. ${ }^{\text {iv }}$ Moreover, given that ESS data are collected approximately every two years, we also include a categorical variable for the round of the survey from 2002 to 2014.

We then use a context-level indicator measuring women's representation in political decisionmaking positions. This variable - a component of the European Index for Gender Equality (EIGE 2015) - gauges women's political power, relying on the share of women and men in national ministries, parliaments and regional assemblies in 2010. The composite measure ranges from 1 to 100 , where 1 stands for no equality and 100 for complete gender equality in political power. The score is highest in Sweden (91.6) and lowest in Hungary (15.2). The scores for all 27 countries are reported in Figure A1 (in the Appendix). Table 1 reports summary statistics for the dependent and independent variables in the pooled sample.

[Table 1 about here] 


\section{Model}

As individuals are nested in countries and the dependent variables are dichotomous (Gelman and Hill 2006) we estimate three sets of multilevel logistic regression models separately for women and men. First, we estimate random-intercepts models, including individual-level variables and the countrylevel variable. These models allow us to assess the differences between women and men in the effects of the life cycle on five forms of political engagement across the European countries analyzed, letting the intercepts vary across countries. In a second step, using random-slopes models we let the coefficients of the life cycle stages vary across countries as well, so as to investigate cross-national differences in the effects of the life course. Eventually, we include cross-level interactions to explore whether the country-level variable - gender equality in political power - is associated with the variation in the life cycle slopes. Owing to limitations of space, we report only the random-intercepts model with the coefficients of interest in Table 2, while the complete models are reported in the Appendix. The coefficients in the models are expressed as log-odds, which provide information about the sign and statistical significance of the coefficients, but do not allow for a straightforward assessment of their magnitude (as is the case in OLS regression). Therefore, to facilitate interpretation, we calculated predicted probabilities and marginal effects from the models and display them using graphs.

\section{Findings}

Table 2 reports the estimates of the multilevel models predicting the probability of involvement in politics among women and men across our sample of European countries. First, as expected, the models indicate that, net of individual and country-level factors, women show lower levels of political engagement than men in all considered forms of such engagement except voting, matching the findings of previous research (Smets and Van Ham 2013). ${ }^{v}$ Computing the probabilities from the estimates, we find that women have a probability of 0.37 of being interested in politics and of 0.45 of feeling close to a party, with men at 0.53 and 0.52 . In terms of more demanding participation, women have a 0.022 chance of working for a party or a political action group and a 0.039 chance of attending a demonstration. The values for men are, respectively, 0.041 and 0.053 . These results confirm the presence of a gender 
gap in various forms of political involvement. The standard deviations of the random-intercepts also show that there is substantial variation across countries in the levels of involvement, in both men's and women's samples.

[Table 2 about here]

The coefficients capturing the association between the stages of the life cycle, political interest, feeling close to a party and voting are in large part positive and statistically significant for both women and men, suggesting that these activities increase over the life course. Among women, instead, working for a party or action group appears to decline until parenthood and then slightly increase, but the effects are mostly insignificant. Men, however, seem to engage more in party activity or in political action groups as they progress through life. In contrast, public demonstrating decreases over the life course for both genders and the effects are statistically significant. To get a better picture of the magnitude of the effects, the panels on the left side of Figure 1 show, for women and men, the predicted probabilities with 95\% confidence intervals of being interested in politics, close to a party, voting, working for a party or political action group, and attending a demonstration. The figure shows that political interest, feeling close to a party and voting increase significantly over the life course of both women and men. Party activity increases among men, whereas it remains rather stable among women. In contrast, the probability of participating in demonstrations decreases among women as well as men, although somewhat less among the latter. Interestingly, the figure shows moderate depressions of "intense" forms of participation (party activity and, more so, demonstrations) among mothers - but not fathers - of preschool children (Elder and Greene 2012; Flanagan et al. 2012; Hooghe 2003; Stoker and Jennings 1995).

[Figure 1 about here]

To further explore gender differences in these effects, the right-hand panels of Figure 1 show the differences between men and women in the probability of engaging in the five acts at each stage of the life cycle with $95 \%$ confidence intervals. These panels allow us to assess whether gaps in political 
involvement enlarge as women enter stages that constrain or marginalize them from the political sphere because of new family roles (Elder and Greene 2012; Flanagan et al. 2012; Stoker and Jennings 1995; Voorpostel and Coffé 2010;). When the confidence intervals of the differences do not overlap the zero line, they are statistically significant. Differences in political interest between men and women enlarge over the life course. The difference is about 0.11 among singles living in the parental home and it increases to 0.17 among partnered individuals and to about 0.20 among parents (regardless of the age of the children). A statistically significant gender gap in party identification emerges among couples and remains stable. Voting seems exempt from gender gaps across the life course. Indeed, voting is argued to be a "habit" that citizens learn and maintain through adulthood (Plutzer 2002), it is a relatively easy form of participation and might therefore be less sensitive to changes in the life course (Coffè and Bolzendahl 2013). Looking at a more demanding form of conventional engagement, party activity, we see that the gap that is present among childless couples enlarges among new parents and then continues to enlarge. Conversely, we do not find significant gender gaps in attending demonstrations, a demanding and unconventional form of engagement.

The overall picture suggests that women are more affected by life cycle constraints than men. This result could be interpreted as a form of "division of political involvement" in the household, which leaves women behind politically. Nevertheless, the similarities between women and men in the case of voting and demonstrations indicate that the picture is more nuanced and that gendered trajectories in political engagement over the life course vary considerably according to the type of involvement. For example, women and men alike might consider voting a civic duty and therefore do not differ in this respect (see Coffè and Bolzendahl 2013). In the case of engagement in demonstrations it could be that it stands "in sharp opposition to the historical dominance of men in politics" (Marien, Hooghe, and Quintelier 2010, p. 204) as a form of non-institutionalized participation. With respect to our hypothesis, leaving the parental home does not entail great differences between women and men, regardless of the type of political involvement, thus confirming hypothesis 1 . Entering a partnership and having children entail a significant gender gap in political interest, party identification and party activity, but not in voting or attending demonstrations, activities that change in a similar way among women and women. Hence, hypotheses 2 and 3 are only partially confirmed. Finally, the patterns of political engagement 
begin to converge during the empty nest phase except for party activity. Therefore, hypothesis 4 is not fully confirmed.

Table 1 also reports the coefficients capturing the effect of women's representation in positions of power. Among women, the effects are positive and significant for political interest (beta $=0.211, \mathrm{p}<$ 0.05 ) and feeling close to a party (beta $=0.209, \mathrm{p}<0.05$ ). The effects on voting, party or political group activity, and demonstrations are positive but not statistically significant. Among men, the coefficients are always positive but not statistically significant. This suggests that, across the pooled sample, at higher levels of political gender equality women increase their involvement in some types of engagement, while men do not. In contexts where women are more present in decision-making institutions, such as the Netherlands, Denmark, Finland or Sweden, female citizens are more involved in politics. In countries like Hungary, Romania, Ireland or Italy, where women are less present in political institutions, it is the opposite. Conversely, the macro-level variable has no effect on men's political engagement, which intuitively makes sense.

The random-slopes models (see Table A2 in the Appendix) allow us to explore the differences in the effect of the life course stages in the different countries. In Figure 2 we plot the country-level predicted differences between women and men in political engagement. As can be see, each type of engagement presents a rather distinct pattern. The gender gaps in political interest display the least crossnational variation, with gender differences becoming wider over the life cycle and then converging during the empty nest phase in virtually all the considered countries. The panels for party identification and voting behavior are more mixed, but overall they suggest little if any change in the gender gap in political engagement over the life course. The differences in party activity suggest that the gender gap widens over the life course in most contexts while, finally, the gender gap in engaging in public demonstrations is rather small throughout the life course and tends to remain rather stable.

[Figure 2 about here]

To account for such cross-national variation we rely on the cross-level interactions between political gender equality and the life cycle slopes (see Table A3 in the Appendix). As interactions are 
particularly tricky to interpret, Figure 3 reports the differences in probabilities between women and men for each outcome at different levels of women's political representation. Specifically, we report the predicted probabilities at the $10^{\text {th }}$ and $90^{\text {th }}$ percentile of the variable, representing, respectively, very low and very high political gender equality. Overall, the gender gaps across life cycle stages in countries with high and low levels of political equality are not statistically different. Regardless of the contextual level of political gender equality, the gender gap is never statistically significant for voting and taking part in demonstrations. Instead, the plot confirms a gender gap in political interest and feeling close to a party in most stages of the life course among countries that have low levels of political gender equality (dotted lines). A gender gap in party activity among childless couples and parents is also evident in these low equality contexts. In contexts with high political gender equality (solid lines), the confidence intervals touch the zero line: hence, the gender gap in involvement is not statistically significant in nearly all activities and stages of the life course except political interest.

Overall, our results indicate women's political representation moderates partially the role of the life cycle by limiting the gender gap in political engagement. However, this holds in relation to feeling close to a party and party activity alone. Thus, the findings indicate that hypothesis 5 , i.e. that the negative effect of life events would be stronger among women in countries with higher levels of societal gender inequality, is only partly confirmed.

[Figure 3 about here]

\section{Conclusions}

This article has investigated cross-national differences in the gender gap in political engagement over the life course in 27 European countries. Multilevel models applied to European Social Survey data explored the extent to which women and men engage in five qualitatively diverse forms of political engagement: political interest, party closeness, voting, party activity and attendance at demonstrations. The article studied whether being in different stages of the life course - such as being in a couple, being a parent of a young child, or in the empty nest phase - affects women's and men's engagement and whether such a relationship varies cross-nationally. 
Our results confirm the main finding from previous studies: regardless of the national context, men are more likely to be politically engaged than women. However, gender differences are more evident in terms of political interest, party identification and party activity than voting and demonstrating. Thus, rather than speaking of a general political gender gap, it is more informative to discuss gaps in specific types of engagement. Moreover, the relationship between life stages and behavior is not uniform across the five types of engagement considered. Women's and men's progress through the various stages is associated with increased political interest, party identification, and voting. Except for voting, this increase is larger for men, therefore producing a gender gap that widens over the course of life. Party activity is stable over the life course among women but increases among men, resulting in a gender gap also in this activity. In contrast, the likelihood of attending demonstrations decreases among both women and men, but again somewhat more acutely among women.

To account for cross-national variation in the gender gap in political engagement, we used a macro-level indicator: the representation of women in political and decision-making positions. Confirming previous studies (Abendschön and Steinmetz 2014; Desposato and Norrander. 2009; Fraile and Gomez 2017) our results revealed a positive direct effect of women's representation at the macrolevel on some forms of women's engagement at the micro-level. A higher presence of women in decision-making positions was also found to limit to some extent the negative effect that certain "dense" stages of the life course have on the gender gap, though not across all types of political engagement.

This research makes several contributions to the literature. First, by taking a broad comparative approach, the article tested whether the findings on the relationship between gender, life course events and political engagement from previous single case studies are generalizable to a larger set of countries. To the best of our knowledge, this is the first article to do so. Moreover, most previous research has centered on one, or at best few, life course events or transitions. In contrast, in the attempt to provide an accurate and nuanced description of the relationship between the life cycle and political engagement, the article uses a fine-grained tool to measure stages of the life course that accounts for seven crucial and qualitatively different phases. Second, our comparative set up allowed us to investigate whether a crucial macro-level characteristic - women's representation in positions of political power - is accountable for the outcome by using cross-level interactions. Third, unlike most prior studies, the 
article covered diverse forms of political involvement, ranging from "invisible" ones, such as political interest and feelings of party affinity, to concrete and, in some cases, demanding forms of participation such as party activity and demonstrations.

It is important to stress that intrinsic limitations of the data restrict the conclusions that we can draw from the analyses. Indeed, longitudinal data are needed to avoid issues of sample selection and endogeneity that may arise when using cross-sectional data to study phenomena, such as life course transitions, that are intrinsically dynamic. Nonetheless, given the lack of comparative longitudinal data for this purpose, we maintain that our seven-category measure of the life cycle is sufficiently detailed to serve as a helpful instrument to test our hypotheses.

Gender inequalities in political engagement are large obstacles on the road towards gender egalitarian societies. By being politically attentive, citizens can make their voices heard and actively pursue relevant objectives to ameliorate their conditions. Thus, on the one hand, the findings from our study are reassuring, as they indicate that both women and men become progressively more engaged in (most of) the considered activities over the life course. On the other hand, the process by which men learn to participate in the political arena is much faster than women's, thus resulting in a gender gap that increasingly widens, especially when it comes to political interest and party activity. Our results suggest that gender-specific opportunities and constraints that are typical of certain stages of the life course are hampering women's - but not men's - chances of being politically involved by slowing down the process that makes citizens more politically aware. Importantly, this hampering effect persists over time so that gender differences in engagement are clearly visible even among parents of older children. Differences eventually decrease in the empty nest phase, but do not disappear completely in some forms of engagement. Cohort effects could also be partially behind the differences that we observe, and future studies will need to address whether, as societies slowly evolve towards greater gender egalitarianism, differences between women and men in political engagement over the life course become narrower. However, despite large increases in women's social standing over the past decades in western countries, our findings point to large gender differences in the extent to which women and men take part in the political arena, suggesting that the road towards egalitarian societies is still long and moving uphill. In this respect, policies favoring gender equality by directly promoting women's presence in the public and 
political field would likely aid the achievement of greater equality between women and men in political engagement. 


\section{References}

Abendschön, Simone, and Stephanie Steinmetz. 2014. The gender gap in voting revisited: Women's party preferences in a European context. Social Politics, 21 (2): 315-44.

Anxo, Dominique, Letizia Mencarini, Ariane Pailhé, Anne Solaz, Maria Letizia Tanturri, and Lennart Flood. 2011. Gender Differences in time use over the life course in France, Italy, Sweden, and the US. Feminist Economics, 17 (3): 159-95.

Baxter, Janeen, Belinda Hewitt, and Michele Haynes. 2008. Life course transitions and housework: Marriage, parenthood, and time on housework. Journal of Marriage and Family, 70 (2): 259-72.

Beauregard, Katrine. 2014. Gender, political participation and electoral systems: A cross-national analysis. European Journal of Political Research, 53 (3): 617-34.

Bhatti, Yosef, and Kasper M. Hansen. 2012. Leaving the nest and the social act of voting: Turnout among first-time voters. Journal of Elections, Public Opinion \& Parties, 22 (4): 380-406.

Bleijenbergh, Inge, and Conny Roggeband. 2007. Equality machineries matter: The impact of women's political pressure on European social-care policies. Social Politics, 14 (4): 437-59.

Boeckmann, Irene, Joya Misra, and Michelle J. Budig. 2015. Cultural and institutional factors shaping mothers' employment and working hours in postindustrial countries. Social Forces, 93 (4): 1301-33.

Buchmann, Marlis C., and Irene Kriesi. 2011. Transition to adulthood in Europe. Annual Review of Sociology, 37: 481-503.

Bukov, Aleksej, Ineke Maas, and Thomas Lampert. 2002 Social participation in very old age: crosssectional and longitudinal findings from BASE. Berlin Aging Study. The Journals of Gerontology. Series B, Psychological Sciences and Social Sciences, 57 (6): 510-17.

Burns, Nancy, Kay L. Schlozman, and Sidney Verba. 1997. The public consequences of private inequality: family life and citizen participation. American Political Science Review, 91 (2): 373-89.

—. 2001. The private roots of public action. Cambridge: Harvard University Press.

Coffé, Hilde, and Catherine Bolzendahl. 2010. Same game, different rules? Gender differences in political participation. Sex Roles, 62 (5-6): 318-33.

Coffé, Hilde, and Selin Dilli. 2015. The gender gap in political participation in Muslim-majority countries. International Political Science Review, 36 (5): 526-44. 
Dalton, Russel. 2004. Democratic challenges, democratic choices: The erosion of political support in advanced industrial democracies. Oxford: Oxford University Press.

Desposato, Scott, and Barbara Norrander. 2009. The gender gap in Latin America: contextual and individual influences on gender and political participation. British Journal of Political Science, 39 (1): 141-62.

Dotti Sani, Giulia M., and Stefani Scherer. 2017. Maternal employment: Enabling factors in context. Work, Employment \& Society, online first.

Eckstein, Katharina, Peter Noack, and Burkhard Gniewosz. 2012. Attitudes toward political engagement and willingness to participate in politics: Trajectories throughout adolescence. Journal of Adolescence, 35 (3): 485-95.

EIGE. 2015. Gender Equality Index 2015. Vilnius: EIGE.

Ekman, Joakim, and Erik Amna. 2012. Political participation and civic engagement: towards a new typology. Human Affairs 22 (3): 283-300.

Elder, Laurel, and Steven Greene. 2012. The politics of parenthood: Causes and consequences of the politicization of the American family. Albany: State University of New York Press.

Ferrin, Mónica, Marta Fraile, and Martiño Rubal. 2015. Young and gapped? Political knowledge of girls and boys in Europe. Political Research Quarterly, 68 (1): 63-76.

Finseraas, Henning, Niklas Jakobsson, and Andreas Kotsadam. 2012. The gender gap in political preferences: an empirical test of a political economy explanation. Social Politics, 19 (2): 219-42.

Flanagan, Constance, and Peter Levine. 2010. Civic engagement and the transition to adulthood. The Future of Children, 20 (1): 159-79.

Flanagan, Constance, Andrea Finlay, Leslie Gallay, and Taehan Kim. 2012. Political incorporation and the protracted transition to adulthood: The need for new institutional inventions. Parliamentary Affairs, 65 (1): 29-46.

Flavin, Patrick, and Michael J. Keane. 2012. Life satisfaction and political participation: Evidence from the United States. Journal of Happiness Studies, 13 (1): 63-78.

Fraile, Marta, and Raul Gomez. 2017. Bridging the enduring gender gap in political interest in Europe: The relevance of promoting gender equality. European Journal of Political Research, online first. 
Fraile, Marta. 2014. Do women know less about politics than men? The gender gap in political knowledge in Europe. Social Politics, 21 (2): 261-89.

Fridkin, Kim L., and Patrick J. Kenney. 2007. Examining the gender gap in children's attitudes toward politics. Sex Roles, 56 (3-4): 133-40.

Gauthier, Anne H., and Frank F. Furstenberg. 2002. The transition to adulthood: A time use perspective. The Annals of the American Academy of Political and Social Science, 580 (1): 153-71.

Gelman, Andrew, and Jennifer Hill. 2006. Data Analysis using regression and multilevel/hierarchical models. Cambridge: Cambridge University Press.

Gilligan, Carol. 1982. In a different voice. Psychological theory and women's development. Cambridge: Harvard University Press.

Goerres, Achim. 2007. Why are older people more likely to vote? The impact of ageing on electoral turnout in Europe. The British Journal of Politics \& International Relations, 9 (1): 90-121.

Goerres, Achim. 2009. The political participation of older people in Europe. The greying of our democracies. London: Palgrave Mcmillan.

Highton, Benjamin, and Raymond E. Wolfinger. 2001. The first seven years of the political life cycle. American Journal of Political Science, 45 (1): 202-9.

Hooghe, Marc. 2003. Why should we be bowling alone? Results from a Belgian survey on civic participation. Voluntas: International Journal of Voluntary and Nonprofit Organizations, 14 (1): 4159.

Inglehart, Ronald, and Pippa Norris. 2003. Rising tide: Gender equality and cultural change around the world. Cambridge University Press.

Inglehart, Ronald. 1997. Modernization and postmodernization. Cultural, economic, and political change in 43 societies. Princeton University Press.

IPU. 2014. Women in national parliaments. Available at: http://www.ipu.org/iss-e/women.htm.

Jennings, M. Kent 1979. Another look at the life cycle and political participation. American Journal of Political Science, 32 (4): 755-71.

Jennings, M. Kent, and Barbara G. Farah. 1980. Ideology, gender and political action: A cross-national survey. British Journal of Political Science, 10 (2): 219-40. 
Jennings, M. Kent, and Markus B. Gregory. 1988. Political involvement in the later years: A longitudinal survey. American Journal of Political Science, 32 (2): 302-16.

Jennings, M. Kent, and Richard G. Niemi. 1981. Generations and politics: A panel study of young adults. Princeton: Princeton University Press.

Killewald, Alexandra. 2013. A reconsideration of the fatherhood premium. Marriage, coresidence, biology, and fathers' wages. American Sociological Review, 78 (1): 96-116.

Kittilson, Miki C. 2008. Representing women: The adoption of family leave in comparative perspective. The Journal of Politics, 70 (2): 323-34.

Kittilson, Miki C., and Leslie Schwindt-Bayer. 2010. Engaging citizens: The role of power-sharing institutions. The Journal of Politics, 72 (4): 990-1002.

Lancee, Bram, and Jonas Radl. 2014. Volunteering over the life course. Social Forces, 93 (2): 833-62.

Lijphart, Arendt. 1997. Unequal participation: democracy's unresolved dilemma. American Political Science Review, 91 (1): 1-14.

Lovenduski, Joni. 1998. Gendering research in political science. Annual Review of Political Science, 1: $333-356$.

Marien, Sofie, Marc Hooghe, and Ellen Quintelier. 2010. Inequalities in non-institutionalised forms of political participation: A multi-level analysis of 25 countries. Political Studies, 58(1): 187-213.

Marini, Margaret M. 1984. Age and sequencing norms in the transition to adulthood. Social Forces, 63 (1): $229-44$.

Morgan, Kimberly J., and Kathrin Zippel. 2003. Paid to care: The origins and effects of care leave policies in Western Europe. Social Politics, 10 (1): 49-85.

Nesbit, Rebecca. 2012. The influence of major life cycle events on volunteering. Nonprofit and Voluntary Sector Quarterly, 41 (6): 1153-74.

Nie, Norman H., Sidney Verba, and Jae-On Kim. 1974. Political participation and the life cycle. Comparative Politics. 6 (3): 319-40.

Nomaguchi, Kei M., and Melissa A. Milkie. 2003. Costs and rewards of children: The effects of becoming a parent on adults' lives. Journal of Marriage and Family, 65 (2): 356-74. 
OECD. 2016. LMF1.6: Gender differences in employment outcomes. Available at: http://www.oecd.org/els/family/database.htm. Accessed May 2017

Oesterle, Sabrina, Monica Kirkpatrick Johnson, and Jeylan T. Mortimer. 2004. Volunteerism during the transition to adulthood: A life course perspective. Social Forces, 82 (3): 1123-49.

Plutzer, Eric. 2002. Becoming a habitual voter: Inertia, resources, and growth in young adulthood. American Political Science Review, 96 (1): 41-56.

Quaranta, Mario. 2016. Leaving home, finding a partner and having kids: Gender differences in political participation across the life course in Italy. Acta Politica, 51 (3): 372-97.

Reingold, Beth, and Jessica Harrell. 2010. The impact of descriptive representation on women's political engagement: Does party matter? Political Research Quarterly, 63 (2): 280-94.

Schlozman, Kay L., Nancy Burns, and Sidney Verba. 1994. Gender and the pathways to participation: The role of resources. The Journal of Politics, 56 (4): 963-90.

— 1999. What happened at work today? A multistage model of gender, employment, and political participation. The Journal of Politics, 61 (1): 29-53.

Schober, Pia S. 2013. The parenthood effect on gender inequality: Explaining the change in paid and domestic work when British couples become parents. European Sociological Review, 29 (1): 74-85.

Smets, Kaat and Catherin van Ham. 2013. The embarrassment of riches? A meta-analysis of individuallevel research on voter turnout. Electoral Studies, 32 (2): 344-59.

Stoker, Laura, and M. Kent Jennings. 1995. Life-cycle transitions and political participation: The case of marriage. American Political Science Review, 89 (2): 421-33.

Teorell, Jan, Mariano Torcal, and Josè R. Montero. 2007. Political participation. Mapping the terrain. In Citizenhip and involvement in European democracies. A comparative analysis, edited by Van Deth, Jan W. and Montero, Josè R. and Westholm, Anders, 334-57. London: Routledge.

Van Ingen, Erik. 2008. Social participation revisited: Disentangling and explaining period, life-cycle and cohort effects. Acta Sociologica, 51 (2): 103-21.

Vassallo, Francesca. 2006. Political participation and the gender gap in European Union member states. Journal of Contemporary European Studies, 14 (3): 411-27. 
Verba, Sidney, Nancy Burns, and Kay L. Schlozman. 1997. Knowing and caring about politics: Gender and political engagement. The Journal of Politics, 59 (4): 1051-72.

Voorpostel, Marieke, and Hilde Coffé. 2010. Transitions in partnership and parental status, gender, and political and civic participation. European Sociological Review, 28 (1): 28-42.

Walby, Silvia. 2004. The European Union and gender equality: Emergent varieties of gender regime. Social Politics, 11 (1): 4-29.

Welch, Susan. 1977. Women as political animals? A test of some explanations for male-female political participation differences. American Journal of Political Science, 21(4): 711-30.

Wolbrecht, Christina, and David E. Campbell. 2007. Leading by example: female members of parliament as political role models. American Journal of Political Science, 51 (4): 921-39.

Wolfinger, Nicholas H., and Raymond E. Wolfinger. 2008. Family structure and voter turnout. Social Forces, 86 (4): 1513-28.

Zukin, Cliff, Scott Keeter, Molly Andolina, Krista Jenkins, and Michael X. Delli Carpini. 2006. A new engagement? Political participation, civic life, and the changing american citizen. Oxford: Oxford University Press. 
Table 1. Summary statistics. Own elaboration of ESS data

\begin{tabular}{|c|c|c|c|c|c|c|}
\hline & \multicolumn{3}{|c|}{ Women } & \multicolumn{3}{|c|}{ Men } \\
\hline & $\begin{array}{c}\text { Mean / } \\
\text { Proportion }\end{array}$ & SD & $\mathbf{N}$ & $\begin{array}{c}\text { Mean / } \\
\text { Proportion }\end{array}$ & SD & $\mathbf{N}$ \\
\hline \multicolumn{7}{|l|}{ Individual-level variables } \\
\hline Political interest & 0.39 & & 97372 & & 0.50 & 91675 \\
\hline Close to a party & 0.46 & & 95439 & & 0.50 & 90269 \\
\hline Vote & 0.77 & & 90660 & & 0.42 & 85089 \\
\hline Work for a party & 0.03 & & 97386 & & 0.22 & 91642 \\
\hline Demonstration & 0.06 & & 97363 & & 0.26 & 91592 \\
\hline Age & 46.47 & 19.91 & 97700 & 45.03 & 19.18 & 91921 \\
\hline \multicolumn{7}{|l|}{ Life cycle: } \\
\hline Living with parents & 0.11 & & 97700 & & 0.37 & 91921 \\
\hline Single & 0.07 & & 97700 & & 0.29 & 91921 \\
\hline Couple, no children & 0.09 & & 97700 & & 0.29 & 91921 \\
\hline Couple, children $0-5$ & 0.16 & & 97700 & & 0.35 & 91921 \\
\hline Couple, children 6-13 & 0.13 & & 97700 & & 0.33 & 91921 \\
\hline Couple, children $14-25$ & 0.14 & & 97700 & & 0.34 & 91921 \\
\hline Empty nest & 0.29 & & 97700 & & 0.43 & 91921 \\
\hline Years of education & 12.46 & 4.32 & 97700 & 12.76 & 4.12 & 91921 \\
\hline Employed & 0.43 & & 97101 & & 0.49 & 91473 \\
\hline Feeling of income (positive) & 0.74 & & 95723 & & 0.41 & 90084 \\
\hline Trust in people & 5.01 & 2.45 & 97344 & 5.14 & 2.38 & 91644 \\
\hline Satisfaction with life & 7.05 & 2.21 & 97237 & 7.06 & 2.15 & 91579 \\
\hline Satisfaction with democracy & 5.21 & 2.42 & 92970 & 5.42 & 2.52 & 89893 \\
\hline \multicolumn{7}{|l|}{ Left right scale: } \\
\hline No answer/don't know & 0.15 & & 97700 & & 0.30 & 91921 \\
\hline Extreme Left & 0.04 & & 97700 & & 0.21 & 91921 \\
\hline Left & 0.22 & & 97700 & & 0.42 & 91921 \\
\hline Centre & 0.30 & & 97700 & & 0.45 & 91921 \\
\hline Right & 0.23 & & 97700 & & 0.45 & 91921 \\
\hline Extreme right & 0.05 & & 97700 & & 0.23 & 91921 \\
\hline \multicolumn{7}{|l|}{ ESS round: } \\
\hline 2002 & 0.13 & & 97700 & & 0.34 & 91921 \\
\hline 2004 & 0.15 & & 97700 & & 0.36 & 91921 \\
\hline 2006 & 0.14 & & 97700 & & 0.34 & 91921 \\
\hline 2008 & 0.17 & & 97700 & & 0.38 & 91921 \\
\hline 2010 & 0.15 & & 97700 & & 0.35 & 91921 \\
\hline 2012 & 0.14 & & 97700 & & 0.35 & 91921 \\
\hline 2014 & 0.12 & & 97700 & & 0.33 & 91921 \\
\hline Country-level variable & \multicolumn{2}{|c|}{ Mean } & \multicolumn{2}{|c|}{ SD } & \multicolumn{2}{|c|}{$\mathbf{N}$} \\
\hline Political equality & \multicolumn{2}{|c|}{48.31} & \multicolumn{2}{|c|}{19.96} & \multicolumn{2}{|c|}{27} \\
\hline
\end{tabular}


Table 2: Logistic multilevel models predicting political engagement among women and men across life cycle transitions in Europe. Own elaboration of ESS data.

\begin{tabular}{|c|c|c|c|c|c|c|c|c|c|c|c|c|c|c|c|c|c|c|c|c|}
\hline & \multicolumn{4}{|c|}{ Political interest } & \multicolumn{4}{|c|}{ Close to a party } & \multicolumn{4}{|c|}{ Vote } & \multicolumn{4}{|c|}{ Work for a party } & \multicolumn{4}{|c|}{ Demonstration } \\
\hline & \multicolumn{2}{|c|}{ Women } & \multicolumn{2}{|c|}{ Men } & \multicolumn{2}{|c|}{ Women } & \multicolumn{2}{|c|}{ Men } & \multicolumn{2}{|c|}{ Women } & \multicolumn{2}{|c|}{ Men } & \multicolumn{2}{|c|}{ Women } & \multicolumn{2}{|c|}{ Men } & \multicolumn{2}{|c|}{ Women } & \multicolumn{2}{|c|}{ Men } \\
\hline & est. & sig. & est. & sig. & est. & sig. & est. & sig. & est. & sig. & est. & sig. & est. & sig. & est. & sig. & est. & sig. & est. & sig. \\
\hline $\begin{array}{l}\text { Intercept } \\
\text {. }\end{array}$ & -1.804 & **** & -1.552 & **** & -1.624 & **** & -1.547 & **** & -0.314 & *** & -0.430 & $* * *$ & -4.640 & $* * *$ & -4.353 & $* * *$ & -3.068 & **** & -2.798 & **** \\
\hline \multicolumn{21}{|l|}{ Life cycle (r.c. living with parents): } \\
\hline Couple, no children & 0.141 & $* * *$ & 0.447 & $* * *$ & 0.108 & ** & 0.225 & **** & 0.142 & $* * *$ & 0.215 & $* * *$ & -0.243 & $* *$ & -0.096 & & -0.477 & $* * *$ & -0.137 & $*$ \\
\hline Couple, children $0-5$ & 0.132 & $* * *$ & 0.566 & $* * *$ & 0.192 & $* * *$ & 0.310 & $* * *$ & 0.436 & $* * *$ & 0.474 & $* * *$ & -0.402 & $* * *$ & 0.031 & & -0.815 & $* * *$ & -0.377 & $* * *$ \\
\hline Couple, children 6-13 & 0.315 & $* * *$ & 0.735 & $* * *$ & 0.327 & $* * *$ & 0.460 & $* * *$ & 0.892 & $* * *$ & 0.823 & $* * *$ & 0.011 & & 0.311 & $* * *$ & -0.581 & $* * *$ & -0.231 & *** \\
\hline Couple, children $14-25$ & 0.629 & $* * *$ & 0.986 & $* * *$ & 0.548 & $* * *$ & 0.663 & $* * *$ & 1.185 & $* * *$ & 1.130 & $* * *$ & 0.111 & & 0.553 & $* * *$ & -0.472 & $* * *$ & -0.170 & $* * *$ \\
\hline Empty nest & 1.074 & $* * *$ & 1.135 & $* * *$ & 0.966 & $* * *$ & 1.029 & $* * *$ & 1.497 & $* * *$ & 1.698 & $* * *$ & -0.167 & * & 0.429 & $* * *$ & -1.241 & $* * *$ & -0.965 & $* * *$ \\
\hline Political equality & 0.211 & $*$ & 0.147 & & 0.209 & $*$ & 0.153 & & 0.166 & & 0.124 & & 0.078 & & 0.001 & & 0.186 & & 0.058 & \\
\hline \multicolumn{21}{|l|}{ Random effects (std. dev.) } \\
\hline Country & \multicolumn{2}{|c|}{0.420} & \multicolumn{2}{|c|}{0.378} & \multicolumn{2}{|c|}{0.425} & \multicolumn{2}{|c|}{0.409} & \multicolumn{2}{|c|}{0.514} & \multicolumn{2}{|c|}{0.549} & \multicolumn{2}{|c|}{0.359} & \multicolumn{2}{|c|}{0.389} & \multicolumn{2}{|c|}{0.625} & \multicolumn{2}{|c|}{0.658} \\
\hline $\mathrm{N}$ & \multirow{2}{*}{\multicolumn{2}{|c|}{$\begin{array}{l}82281 \\
97421\end{array}$}} & \multirow{2}{*}{\multicolumn{2}{|c|}{$\begin{array}{l}78906 \\
95448\end{array}$}} & \multirow{2}{*}{\multicolumn{2}{|c|}{$\begin{array}{l}80810 \\
97578\end{array}$}} & \multirow{2}{*}{\multicolumn{2}{|c|}{$\begin{array}{l}77733 \\
97578\end{array}$}} & 7732 & & 739 & & 8228 & & 7888 & & 822 & & 788. & \\
\hline BIC & & & & & & & & & 717 & & 661 & & 2008 & & 2924 & & 324 & & 370 & \\
\hline
\end{tabular}


Figure 1: Probabilities of women and men (on the left), and differences in the probabilities between women and men (on the right) of being engaged in politics across life course stages in 27 European countries, with 95\% confidence intervals. Own elaboration of ESS data.
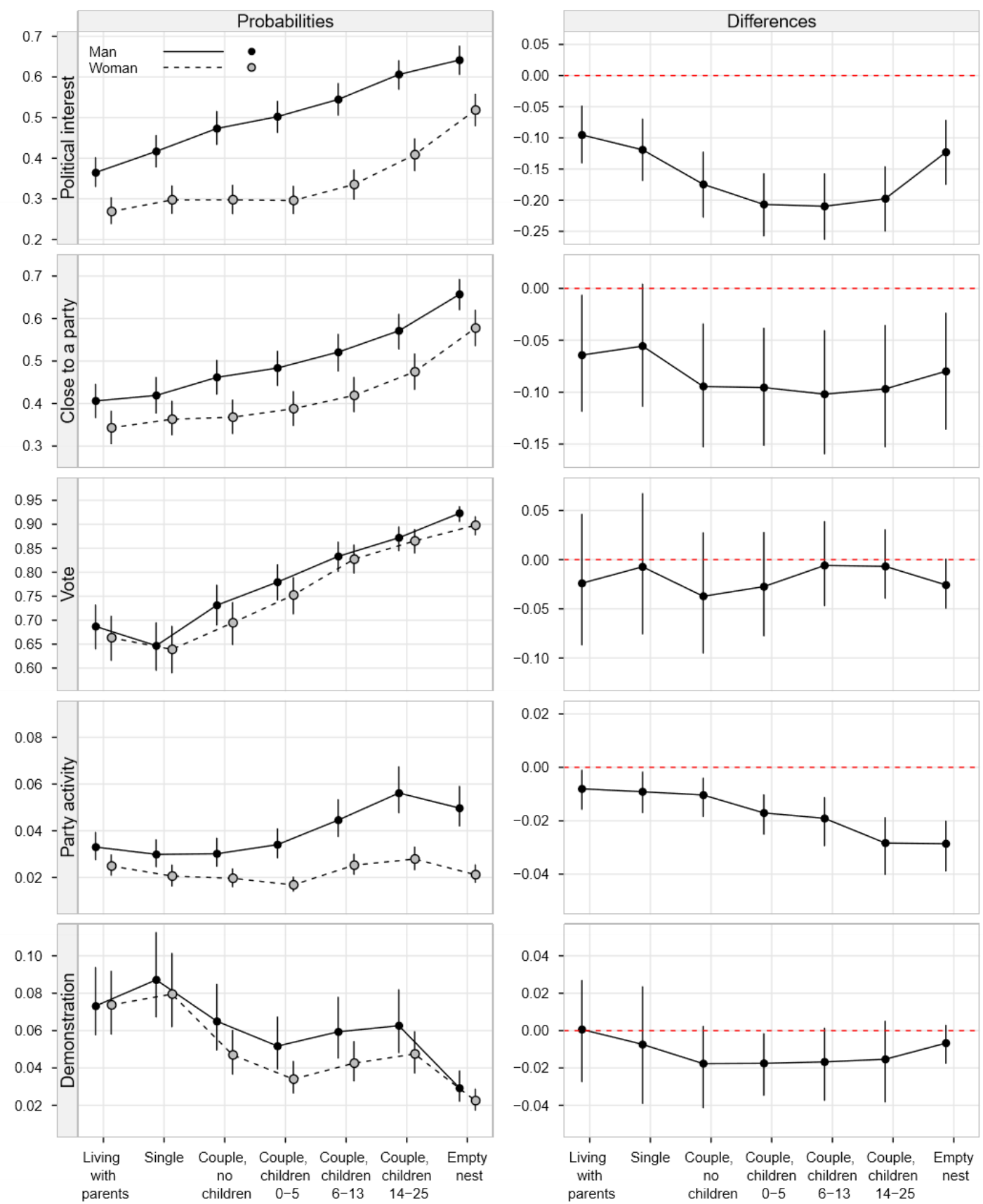
Figure 2: Differences in the probability between women and men of being engaged in politics across life course stages in 27 European countries. Own elaboration of ESS data.
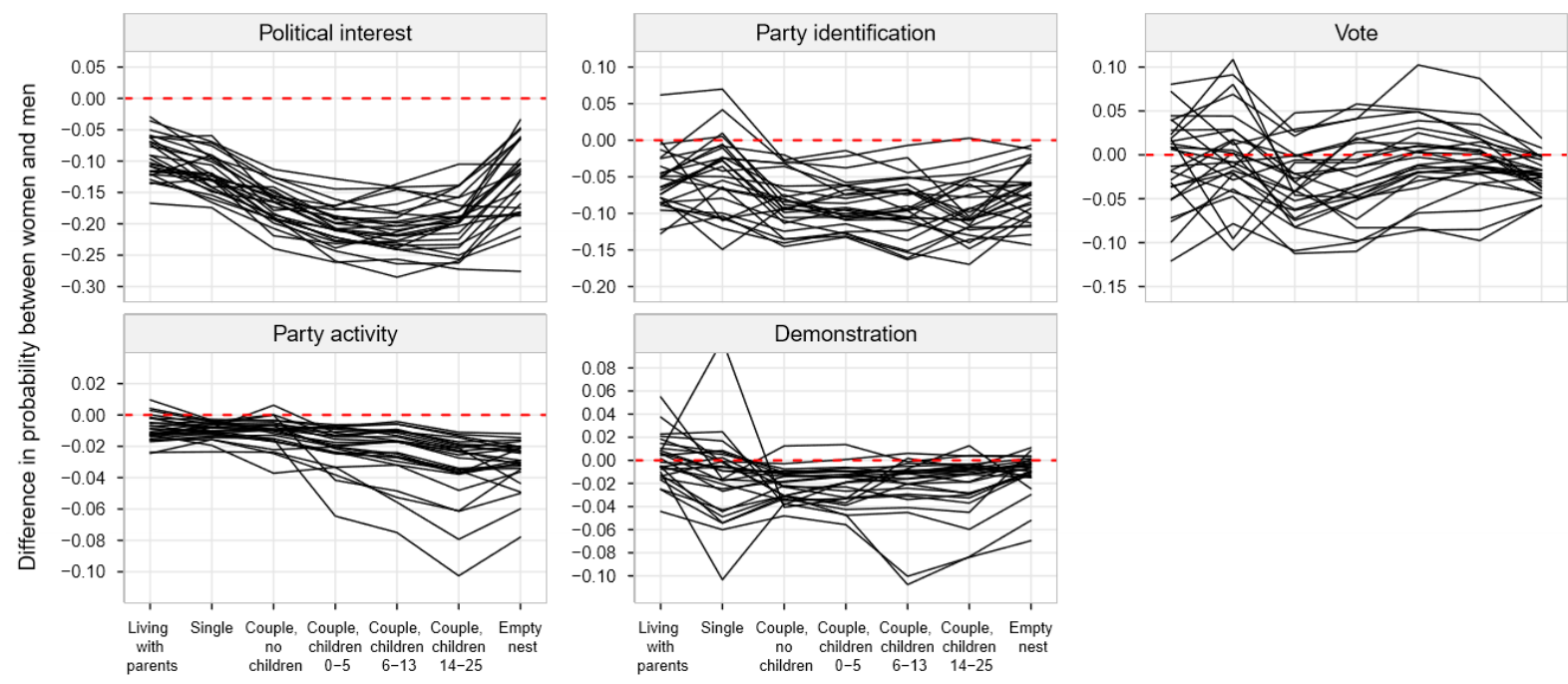
Figure 3: The differences in the probability between women and men of being engaged in politics across the life course stages at low $\left(10^{\text {th }}\right.$ percentile $)$ and high $\left(90^{\text {th }}\right.$ percentile $)$ levels of political equality, across 27 European countries, with 95\% confidence intervals. Own elaboration of ESS data.
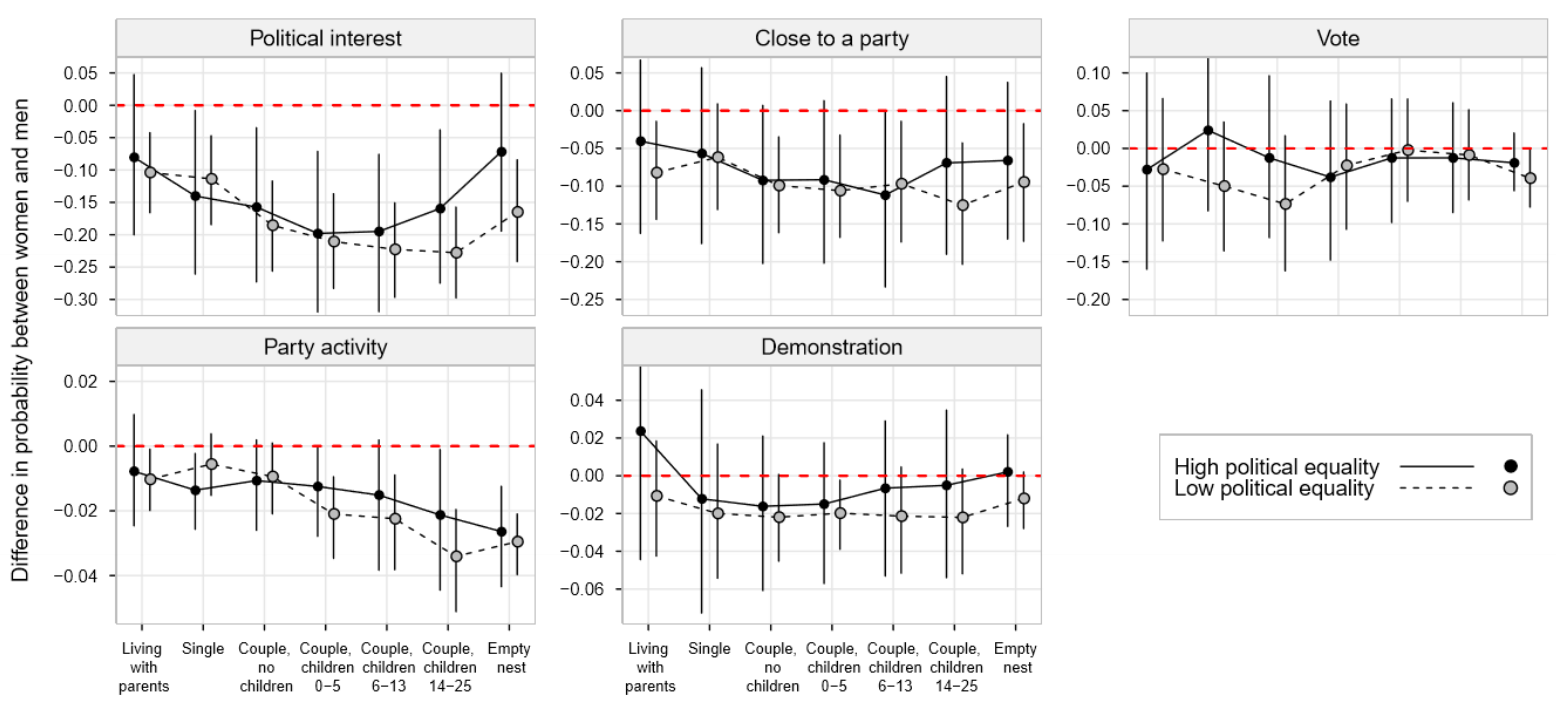

${ }^{1}$ Education is recognized as crucial in facilitating women's political engagement. However, it also facilitates men's engagement, thus it does not play a pivotal role in narrowing political gaps (Burns, Schlozman, and Verba 2001).

${ }^{\text {ii }}$ A longitudinal survey would of course provide a more precise look at the link between political involvement and stage of life but, unfortunately, comparative panel data including both information on the family structure and political engagement are not available. Thus, the ESS remains a valuable alternative.

iii This variable is originally measured using an ordinal item with four response categories: very interested, quite interested, hardly interested, not at all interested. We dichotomized it for coherence with the other items, aggregating the first two vs. the latter two categories. 
iv This variable is originally continuous and ranges from 0 (extreme left) to 10 (extreme rights). It was recoded as follows: $1=$ no answer/don't know; $2=0-1$, as extreme left; $3=2-4$, as left; $4=5$, as center; $5=6-8$, as right; $6=9-10$, as extreme right.

${ }^{v}$ Probabilities and differences in probabilities are computed at the means of the covariates. Gender differences were also tested by running pooled models with both women and men and interacting the life cycle variable with a dummy for gender. We opted for separated models for men and women as the subsequent models, if pooled, would include three-way interactions (between gender, life cycle and political equality) and country random-slopes for the individual-level terms of such interactions (gender and life cycle), complicating the estimation of the coefficients. The model specification separating men's and women's samples is simpler to estimate, yet it leads to similar results to the pooled model specification. 